\title{
New data on the taxonomy and geographic distribution of Oriental species of the genus Coptocercus Hope, 1841 (Coleoptera: Cerambycidae: Phoracanthini)
}

\author{
Новые данные по таксономии и распространению \\ ориентальных видов рода Coptocercus Hоре, 1841 \\ (Coleoptera: Cerambycidae: Phoracanthini)
}

\author{
Alexandr I. Miroshnikov ${ }^{1,2}$ \\ А.И. Мирошников ${ }^{1,2}$
}

\footnotetext{
${ }^{1}$ Russian Entomological Society, Krasnodar, Russia. E-mail: miroshnikov-ai@yandex.ru

${ }^{2}$ Sochi National Park, Moskovskaya str., 21, Sochi, Krasnodar region 354002, Russia.

${ }^{1}$ Русское энтомологическое общество, Краснодар, Россия.

${ }^{2}$ Сочинский национальный парк, ул. Московская, 21, Сочи, Краснодарский край 354002, Россия.
}

KEY WORDS: Coleoptera, Cerambycidae, Phoracanthini, Coptocercus, Indochina, Borneo, first records, Coptocercus sumatranus, Thailand, Malaysia, Indonesia.

КЛЮЧЕВЫЕ СЛОВА: Coleoptera, Cerambycidae, Phoracanthini, Coptocercus, Индокитай, Борнео, первые находки, Coptocercus sumatranus, Таиланд, Малайзия, Индонезия.

ABSTRACT. Based on the first records of Coptocercus sumatranus Hüdepohl, 1992, stat.n., from the western and earstern parts of Malaysia, as well as from Thailand, the genus Coptocercus Hope, 1841 is new to the faunas of Indochina and Borneo. A new taxonomic status and a new synonym are established: Coptocercus sumatranus Hüdepohl, 1992, stat.n. = Coptocercus javanicus Wang, 1995, syn.n. Morphological features of C. sumatranus and C. quatuordecimsignatus Schwarzer, 1926 are provided, the main differences between these species outlined, and a map of their distributions is given.

РЕЗЮМЕ. На основе первых находок Coptocercus sumatranus Hüdepohl, 1992, stat.n. в западной и восточной частях Малайзии, а также в Таиланде род Coptocercus Hope, 1841 отмечается как новый для фаун Индокитая и Борнео. Установливаются новый таксономический статус и новый синоним: Coptocercus sumatranus Hüdepohl, 1992, stat.n. = Coptocercus javanicus Wang, 1995, syn.n. Приводятся морфологические особенности C. sumatranus и C. quatuordecimsignatus Schwarzer, 1926 и отличия между ними, а также даётся карта их распространения.

\section{Introduction}

During a study of a rich material collected in the western and eastern parts of Malaysia in 2007 and 2015, a species of the genus Coptocercus Hope, 1841 has been found. The first formal records of the genus in Indochina and Borneo are thus provided.
Initially, two males and three females available in this material were identified as representing Coptocercus quatuordecimsignatus sumatranus Hüdepohl, 1992, a subspecied described from northern Sumatra based on the female holotype. A further, more profound study of the Malaysian specimens and them comparison with the holotypes of C. q. sumatranus, C. q. celebensis Schwarzer, 1926, C. q. quatuordecimsignatus Schwarzer, 1926 and a number of non-type specimens of the nominative subspecies not only confirmed the initial identification as being correct, but also led to the conclusion of the species independence of $C$. sumatranus. Later, one male (from Malacca) and one female (collected in Thailand), both received from the Natural History Museum of Denmark (NHMD), as well as the Sumatran female obtained from Dr. Sergey V. Murzin (Moscow, Russia), only strengthened the opinion of the full species status of C. sumatranus.

Besides this, when studying the original description of Coptocercus javanicus Wang, 1995, the attention has been paid to the very strong similarity of this species to C. sumatranus. However, in the revision of the genus Coptocercus [Wang, 1995], in which C. javanicus was originally described, it was only compared to C.pascoei Wang, 1995 (Kai Islands, Indonesia), while C. quatuordecimsignatus and its subspecies, including C. sumatranus, were completely omitted.

Through the courtesy of Dr. Maxwell V.L. Barclay, Dr. Michael F. Geiser and Mr. Keita Matsumoto (BMNH) I have received high-quality pictures of all specimens of the type series, namely, the holotype (male) and two paratypes (both females) of C. javanicus (Figs 12-17). Their detailed study revealed the identity of C. sumatranus and C.javanicus. 

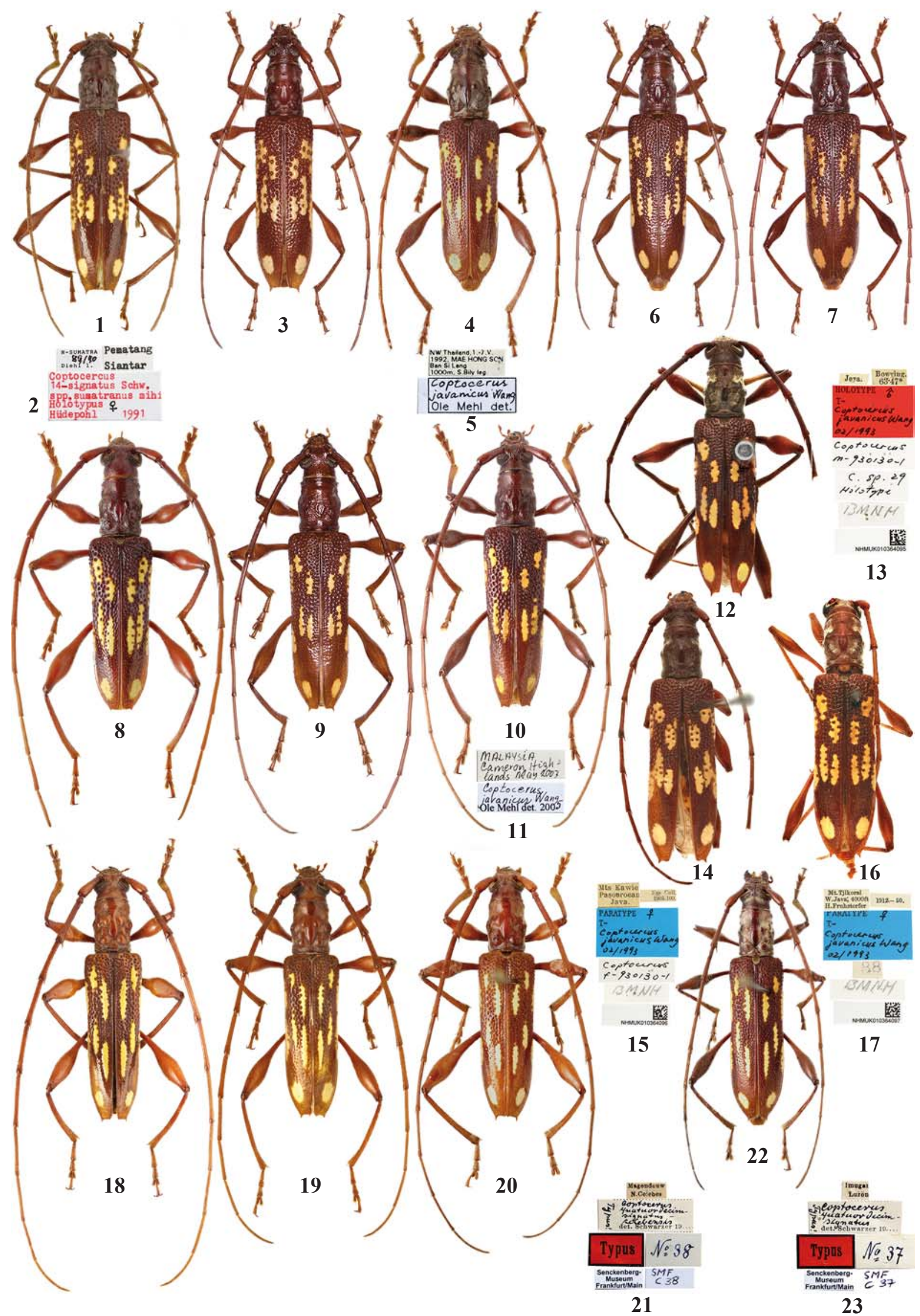
It seems also noteworthy that both above specimens of $C$. sumatranus from NHMD stem from the collection of the late Ole Mehl, a remarkable expert in longicorn beetles, who had determined them as C.javanicus (Figs 5-11). I am inclined to believe that they could have been compared to the holotype and paratypes of this taxon kept in BMNH. All this seems to only support my conclusion of their synonymy.

The material this paper is based upon comes from the following institutional and private collections: BM Bishop Museum (Honolulu, USA); BMNH - Natural History Museum, London (United Kingdom); NHMD Natural History Museum of Denmark, University of Copenhagen (Copenhagen, Denmark); SMF — Senckenberg Forschungsinstitut und Naturmuseum Frankfurt (Frankfurt am Main, Germany); ZSM - Zoologische Staatssammlung München (München, Germany); cAM coll. Alexandr Miroshnikov (Krasnodar, Russia); cEC - coll. Estan Cabigas (Makati City, Philippines); cEV — coll. Eduard Vives (Barcelona, Spain); cSM coll. Sergey Murzin (Moscow, Russia).

\section{Coptocercus sumatranus Hüdepohl, 1992, stat.n.} Figs 1-17, 25-35, 44.

Coptocercus quatuordecimsignatus sumatranus Hüdepohl, 1992: 412. Type locality: N Sumatra, Pematang Siantar (according to the original description and the label of the holotype).

Coptocercus javanicus Wang, 1995: 514 (Indonesia: Java), syn.n. (see Remarks).

MATERIAL. Holotype, + (ZSM) (Figs 1-2), [Indonesia] NSumatra, 89/90, Diehl 1. / Pematang Siantar / Coptocercus 14signatus Schw. ssp. sumatranus mihi, Holotypus + , Hüdepohl 1991 $1+$ (cSM) (Fig. 3), Indonesia, W Sumatra, Talang Mt., 1.04.1992, unknown collector; $10^{7}$ (cAM) (Fig. 8), W Malaysia, Pahang, Bukit Fraser [= Fraser's Hill], $3^{\circ} 43^{\prime} \mathrm{N} / 101^{\circ} 44^{\prime} \mathrm{E}, 1000-1300 \mathrm{~m}, 1-$ 13.05.2007, leg. V. Tuzov; $10^{7}$ (NHMD) (Figs 10-11), W Malaysia, Cameron Highlands, May 2003, native collector / Coptocerus [sic] javanicus Wang, Ole Mehl det. 2005 + Coptocercus sumatranus Hüdepohl, 1992, A. Miroshnikov det., 2016; 10, 19 (cAM) (Figs 6 , 9), same locality, but Tanah Rata, 04.2015, native collector; 1 \% (NHMD) (Figs 4-5), NW Thailand, Mae Hong Son, Ban Si Lang, $1000 \mathrm{~m}, 1-7.05 .1992$, leg. S. Bily / Coptocerus [sic] javanicus Wang, Ole Mehl det. + Coptocercus sumatranus Hüdepohl, 1992, A. Miroshnikov det., 2016; 1 ㅇ (cAM) (Fig. 7), E Malaysia, Sabah, Crocker Range, 11.2015, native collector; 1 오 (cAM), same label; holotype $\sigma^{\prime}$ (BMNH) (photographs by Keita Matsumoto, copyright Natural History Museum, London; Figs 12-13), "Java."/ "Bowring. 63-47*" / "Holotype Or T- Coptocercus javanicus Wang 02/1993" / "Coptocercus m-930130-1" / "C. sp. 29 Holotype" / "BMNH" / "NHMUK010364095" + Coptocercus sumatranus Hüdepohl, 1992, A. Miroshnikov det., 2016; paratype + (BMNH) (photographs by Keita Matsumoto, copyright Natural History Museum, London; Figs 14-15), "Mts Kawie [now Mts Butak], Pasoeroean, Java." "Fry Coll. 1905-100." / "Paratype o T-Coptocercus javanicus
Wang 02/1993" / "Coptocercus f-930130-1" / "BMNH" / "NHMUK010364096" + Coptocercus sumatranus Hüdepohl, 1992, A. Miroshnikov det., 2016; paratype + (BMNH) (photographs by Keita Matsumoto, copyright Natural History Museum, London; Figs 16-17), "Mt. Tjikorai [now Mt. Cikuray], W. Java, 4000ft, H. Fruhstorfer" / "1912-50." / "Paratype O T-Coptocercus javanicus Wang 02/1993" / "88" / "BMNH" / "NHMUK010364097" + Coptocercus sumatranus Hüdepohl, 1992, A. Miroshnikov det., 2016.

COMPARATIVE MATERIAL. Coptocercus quatuordecimsignatus: see below; Coptocercus shutaea: holotype, $\sigma^{7}$ (BM) (photograph by Nobuo Ohbayashi), Papua New Guinea, Bismarck Archipelago, New Ireland, Schleinitz Mts, $3^{\circ} 10^{\prime} \mathrm{S} / 151^{\circ} 58^{\prime} \mathrm{E}$, October 1959, leg. W.W. Brandt.

DIAGNOSIS. This species resembles C. quatuordecimsignatus (as originally described as its subspecies), but differs clearly by the structure and location of the longitudinal yellow stripes of the elytra, as well as by the conformation of the genitalia. In C. sumatranus stat.n., the stripe at the suture in the basal part of the elytra is short, about equal in length to the adjacent stripe behind the humeri, while the stripe at the suture in the apical part of the elytra is barely or weakly displaced downward relative to the adjacent stripe (Figs 1, 3$4,6-10,12,14,16,24-35)$. In C. quatuordecimsignatus, the stripe at the suture in the basal part of the elytra is strongly or very strongly elongated, 1.43-2.60 times as long as the adjacent stripe behind the humeri (the length ratio of these stripes in all 9 specimens studied is as follows: 1.43, 1.51, $1.54,1.59,1.63,1.71,1.80,2.05,2.60)$, while the stripe at the suture in the apical part of the elytra is very strongly displaced downward relative to the adjacent stripe (Figs 18-20, 22, 3643). In comparison with $C$. quatuordecimsignatus, in $C$. sumatranus stat.n., the parameres are somewhat more weakly narrowed towards the apex, the penis is slightly wider, including its apical part, and clearly narrowed before the apex. In $C$. quatuordecimsignatus, the penis in the apical part is regularly narrowed towards the apex, without a constriction before the latter. In C. sumatranus stat.n., tergite VIII is clearly transverse, $1.20-1.23$ times as wide as long, while in C. quatuordecimsignatus, tergite VIII is about equal in width and length, only barely transverse. Coptocercus sumatranus stat.n. differs from the typical form C. quatuordecimsignatus also by a noticeably darker coloration both of the head and pronotum and by a somewhat different coloration of the elytra. Besides this, the elytral puncturation in C. sumatranus stat.n. is generally somewhat larger, especially so in the Sumatran specimens, than in C. quatuordecimsignatus, even though, based on this feature alone, some specimens of the former species differ quite weakly from material of the latter species. Coptocercus sumatranus stat.n. can also be compared to C. shutaea Wang, 1995 (Papua New Guinea, Bismarck Archipelago; Solomon Islands), but differs, like $C$. quatuordecimsignatus, by the structure of the yellow stripes on the elytra, as well as by the apical, oval, yellow spot on each elytron being more distant from the latter's apex.

Figs 1-23. Coptocercus spp., habitus and labels: 1-17 - C. sumatranus stat.n.; 18-21 - C. quatuordecimsignatus s. str.; 22-23 - C. quatuordecimsignatus celebensis; 1-2 - holotype; 3 - W Sumatra, Mt. Talang; 4-5 - NW Thailand, Mae Hong Son, Ban Si Lang; 6, 9 - W Malaysia, Pahang, Cameron Highlands, Tanah Rata; 7 — E Malaysia, Sabah, Crocker Range; 8 - W Malaysia, Pahang, Bukit Fraser; $10-11$ W Malaysia, Pahang, Cameron Highlands; 12-13 - holotype of C. javanicus; 14-15 — paratype of C. javanicus (Mt. Kawie; now Mt. Butak); 16-17 - paratype of C.javanicus (Mt. Tjikorai; now Mt. Cikuray) (12-17 — photographs by Keita Matsumoto, copyright Natural History Museum,

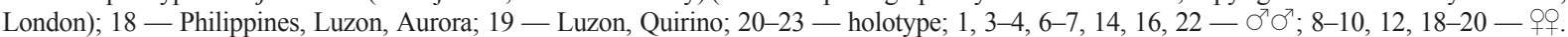

Рис. 1-23. Coptocercus sumatranus stat.n., общий вид и этикетки: 1-17 - C. sumatranus stat.n.; 18-21 - C. quatuordecimsignatus s. str.; 22-23 - C. quatuordecimsignatus celebensis; 1-2 - голотип; 3 - 3 Суматра, гора Таланг; 4-5 - С3 Таиланд, Мае Хонг Сон (Мэхонгсон), Бан Си Ланг; 6, 9 - 3 Малайзия, Паханг, Камерон Хайлендс, Танах Рата; 7 - В Малайзия, Сабах, Крокер Рендж; 8 - 3 Малайзия, Паханг, Букит Фрейзер; 10-11 - 3 Малайзия, Паханг, Камерон Хайлендс; 12-13 - голотип C. javanicus; 14-15 - паратип C. javanicus (гора Бутак); 16-17 - паратип C. javanicus (гора Чикурай); 18 - Филиппины, Лусон, Аврора; 19 - Лусон, Кирино; $20-23$ - голотип; 1, 3-4, 6-7, 14, 16, 22 - б $\sigma^{7} ; 8-10,12,18-20-$ о․ 


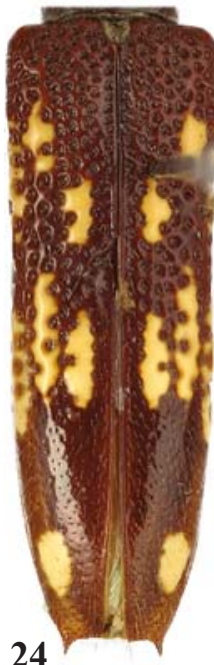

24

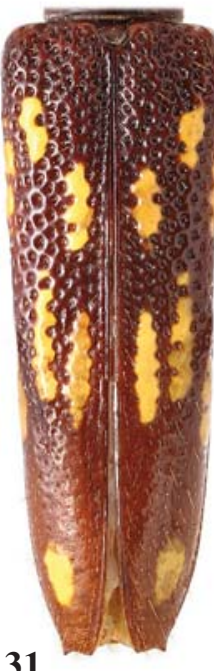

31

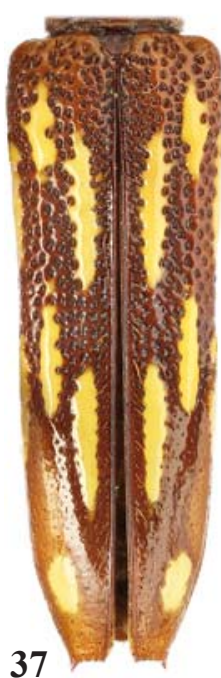

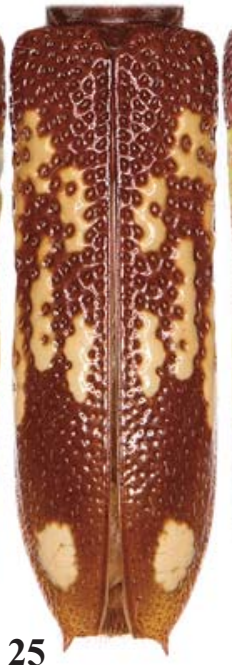

25
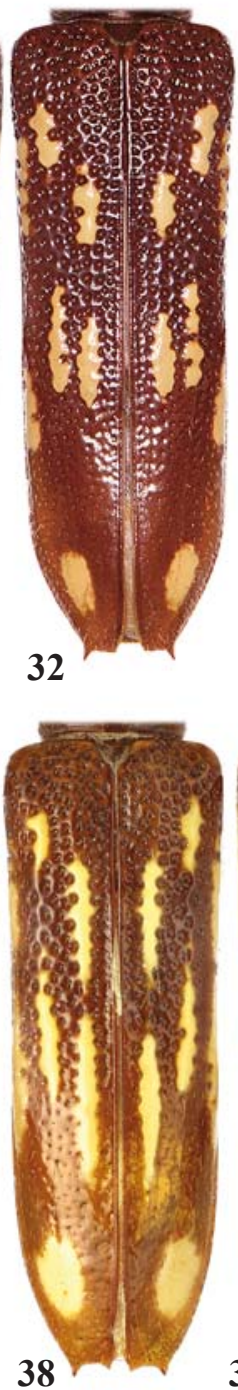
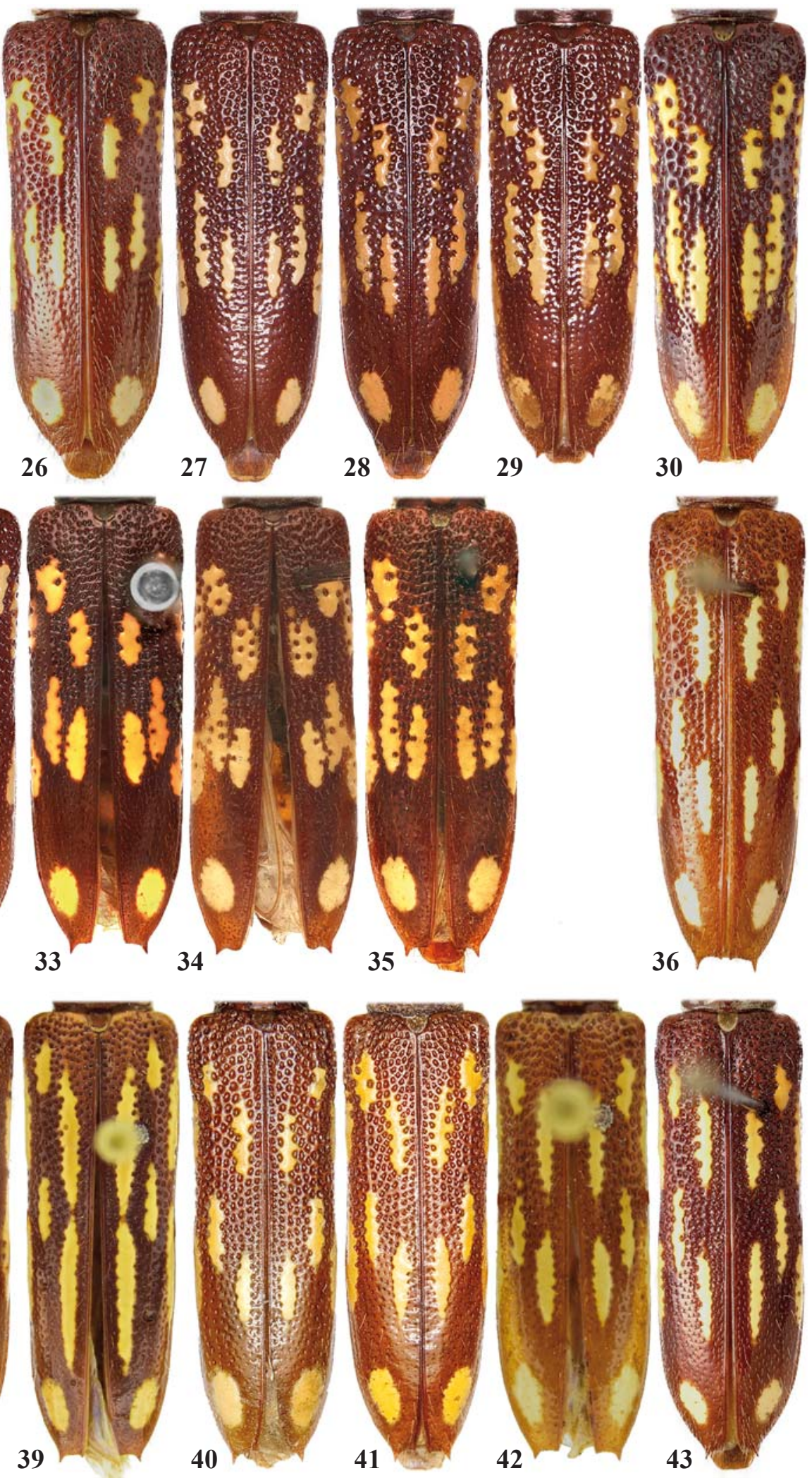

Figs 24-43. Coptocercus spp., elytra: 24-35 - C. sumatranus stat.n.; 36-42 - C. quatuordecimsignatus s. str.; $43-$ holotype of C. q. celebensis; 24 - holotype; 25 - W Sumatra, Mt. Talang; 26 - NW Thailand, Ban Si Lang; 27, 32 - W Malaysia, Pahang, Cameron Highlands, Tanah Rata; 28-29 — E Malaysia, Sabah, Crocker Range; 30 - W Malaysia, Pahang, Bukit Fraser; 31 - W Malaysia, Pahang, Cameron Highlands; 33 - holotype of C. javanicus; 34 - paratype of C. javanicus (Mt. Kawie; now Mt. Butak); 35 - paratype of C. javanicus (Mt. Tjikorai; now Mt. Cikuray) (33-35 - photographs by Keita Matsumoto); 36 - holotype; 37- Philippines, Luzon, Aurora; 38 - Luzon, Quirino; 39 Philippines, Negros; 40-41 — Philippines, Mindanao, Bukidnon; 42 — Luzon, Mountain Province (39, 42 — photographs by Katja Neven; 40 -

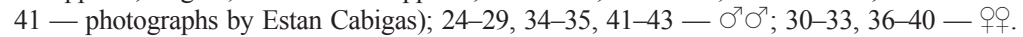


REMARKS. Among the most important typical morphological features of Coptocercus sumatranus stat.n. are both the structure and location of the longitudinal yellow stripes on the elytra as described above. All three specimens from the type series of C. javanicus, i.e. the holotype (male) and two paratypes (both females), show exactly such peculiarities which, based on the material studied, fail to extend beyond of the range of variability of $C$. sumatranus stat.n. No significant differences between Javanese and all other specimens known to me in body coloration, the structure of the antennae, including the spines at the apex of several basal antennomeres, the sculpture of the pronotum, the location of the apical yellow spot of the elytra, etc. are found either. The holotype and the paratypes of $C$. javanicus differ from the holotype of C. sumatranus stat.n. only by the somewhat less coarse puncturation on most of the elytra. However, the puncturation of the elytra of this species is generally variable to some degree, but revealing a pattern in this character in the different populations is yet impossible.

Thus, taking into account all above, including the characters given in the "Diagnosis" section, I allot here a new taxonomic status and propose a new synonym: Coptocercus sumatranus Hüdepohl, 1992, stat.n. = Coptocercus javanicus Wang, 1995, syn.n.

MORPHOLOGICAL NOTES. The specimens of Coptocercus sumatranus, stat.n. considered here are characterized by the following features.

Males. Body length 18.0-22.3 mm, humeral width 4.2$5.1 \mathrm{~mm}$. Antennae much longer than body, about reaching the apex of elytra by apex of antennomere 7. Pronotum noticeably elongated, 1.33-1.39 times as long as wide at base; sculpture of disk variable, can partly be strongly wrinkled between tubercles. Apical external angle of elytra with a tooth strongly variable in length.

Females. Body length 15.0-21.1 mm, humeral width 3.3-4.9 mm. Antennae noticeably longer than body, extended behind apex of elytra by antennomere 9. Pronotum 1.331.36 times as long as wide at base (versus 1.30 in holotype female). Apical external angle of elytra like in males.

DISTRIBUTION (Fig. 44). Indonesia: Sumatra and, taking into account the above synonymy, Java.

Based on the studied material, C. sumatranus stat.n. is being recorded here in Indochina (Thailand and western Malaysia) and Borneo (eastern Malaysia) for the first time.

The female referred to on (https://www.flickr.com/ photos/angiud/25402840506) as "Coptocercus sp." and originating from Khao Ram Rome Mountain, southern Thailand undoubtedly belongs to this species.

Coptocercus quatuordecimsignatus Schwarzer, 1926 Figs 18-23, 36-44.

Coptocerus (sic) quatuordecimsignatus Schwarzer, 1926: 8. Type locality: Philippines, Luzon, Imugan (according to the original description and the label of the holotype).

Coptocercus quatuordecimsignatus: Hüdepohl, 1990: 86 (Philippines: Luzon; Negros).

Coptocerus (sic) quatuordecimsignatus celebensis Schwarzer, 1926: 8. Type locality: N Celebes (now N Sulawesi), Magondouw (= Mongondow) (according to the original description and the label of the holotype).
Coptocercus quatuordecimsignatus celebensis: Hüdepohl, 1992: 412.

MATERIAL. Coptocercus q. quatuordecimsignatus: Philippines: holotype, $\sigma$ (SMF) (Figs 20-21), Imugan, Luzon / Coptocerus [sic] quatuordecimsignatus det. Schwarzer, 19..[?], Typus! / Typus (upperside), № 37 (underside) / Senckenberg-Museum Frankfurt/Main (upperside), SMF C 37 (underside); $10^{7}$ (cEV) (Fig. 18), E Luzon, Aurora, 06.2007, native collector; $10^{7}$ (cEV) (Fig. 19), Luzon, Quirino, 04.2014, native collector; $10^{7}$ (ZSM), Negros, 06.[19]85 / Coptocercus 14-signatus Schw. Hüdepohl det. [19]86; 1 우 (ZSM), Mountain Province / Luzon, 06.[19]86; $10^{T}$ (cEC) (photograph), Mindanao, Bukidnon, 05.2003; 1 ㅇ (cEC) (photograph), Mindanao, Bukidnon, 09.2003.

Moreover, a picture of the female presented on the web (http:// salagubang.net/pages/species/species cer s0643.html) has been thoroughly examined.

Coptocercus q. celebensis: holotype, + (SMF) (Figs 22-23), [Indonesia] Magondouw [= Mongondow], N. Celebes / Coptocerus [sic] quatuordecimsignatus celebensis det. Schwarzer, 19..[?], Typus! / Typus (upperside), № 38 (underside) / Senckenberg-Museum Frankfurt/Main (upperside), SMF C 38 (underside).

REMARKS. Coptocercus q. celebensis (Figs 22, 43), described from a single female from northern Sulawesi, Indonesia [Schwarzer, 1926], differs from the nominate subspecies (Figs 18-20, 36-42) by a generally darker coloration; so far I know this taxon only from the holotype. It seems noteworthy that, based on the pictures obtained from Mr. Estan Cabigas, Makati City, Philippines, the head and pronotum of both the male and females from Mindanao are coloured about the same as in the holotype of C. q. celebensis. Possibly, the south of the Philippine archipelago is inhabited by populations consisting (at least partly) of individuals characterized by certain transitional (mixed) features of their coloration.

DISTRIBUTION (Fig. 44). Philippines: Luzon, Negros, Mindanao; Indonesia: Northern Sulawesi.

ACKNOWLEDGEMENTS. I am very grateful to Michael Balke and Katja Neven (ZSM), Maxwell V.L. Barclay and Michael F. Geiser (BMNH), Damir Kovac and Andrea Hastenpflug-Vesmanis (SMF), Alexey Yu. Solodovnikov and Sree Gayathree Selvantharan (NHMD) for the opportunity to study the museum material under their care while Sergey V. Murzin (Moscow, Russia) and Eduard Vives (Barcelona, Spain) have provided some specimens from their private collections. My sincere thanks also go to Kirill V. Makarov (Moscow Pedagogical State University, Russia) who has helped with the preparation of many photographs, again to Maxwell V.L. Barclay, Michael F. Geiser, as well as to Keita Matsumoto (BMNH) for the photographs of the type specimens of $C$.javanicus, again to Katja Neven for the pictures of the specimens of $C$. q. quatuordecimsignatus from the Hüdepohl's collection (ZSM), Estan Cabigas (Makati City, Philippines) for the photographs of C. q. quatuordecimsignatus. I am deeply indebted to Dmitry Telnov (Entomological Society of Latvia, Riga), Mariya A. Salnitskaya (St. Petersburg, Russia), again to Alexey Yu. Solodovnikov and Sree Gayathree Selvantharan who have helped a lot in my prompt receipt of the material to examine, to Qiao Wang (Institute of Agriculture and Environment, Massey University, Palmerston North, New Zealand) for the electronic copies of several his papers, to Alexey A.

Рис. 24-43. Coptocercus spp., надкрылья: 24-35 - C. sumatranus stat.n.; 36-42 - C. quatuordecimsignatus s. str.; 43 - голотип C. q. celebensis; 24 - голотип; 25 - 3 Суматра, гора Таланг; 26 - С3 Таиланд, Мае Хонг Сон, Бан Си Ланг; 27, 32 - 3 Малайзия, Паханг, Камерон Хайлендс, Танах Рата; 28-29 - В Малайзия, Сабах, Крокер Рендж; 30 - 3 Малайзия, Паханг, Букит Фрейзер; 31 — 3 Малайзия, Паханг, Камерон Хайлендс; 33 - голотип C. javanicus; 34 - паратип C. javanicus (гора Бутак); 35 - паратип C. javanicus (гора Чикурай); 36 - голотип; 37- Филиппины, Лусон, Аврора; 38 - Лусон, Кирино; 39 - Филиппины, Негрос; 40-41 - Филиппины, Минданао, Букиднон; 42 - Лусон, Горная провинция; 24-29, 34-35, 41-43 — о о7; 30-33, 36-40 — 
Klimenko (Tver, Russia) who generously presented me with some specimens of $C$. sumatranus.

\section{References}

Schwarzer B. 1926. Beiträge zur Kenntnis der Cerambyciden (Col.) // Entomologische Mitteilungen. Bd.15. Nr.1. S.6-14.
Hüdepohl K.-E. 1990. The longhorn beetles of the Philippines. Part 2 // Entomofauna. Zeitschrift für Entomologie. Bd.11. H.3/1. S.45-102.

Hüdepohl K.-E. 1992. Über südostasiatische Cerambyciden X (Coleoptera, Cerambycidae) // Entomofauna. Zeitschrift für Entomologie. Bd.13. H.25. S.409-421.

Wang Q. 1995. A revision of the Australasian genus Coptocercus Hope (Coleoptera: Cerambycidae: Phoracanthini), with descriptions of twenty-one new species // Invertebrate Taxonomy. Vol.9. No.3. P.447-528.

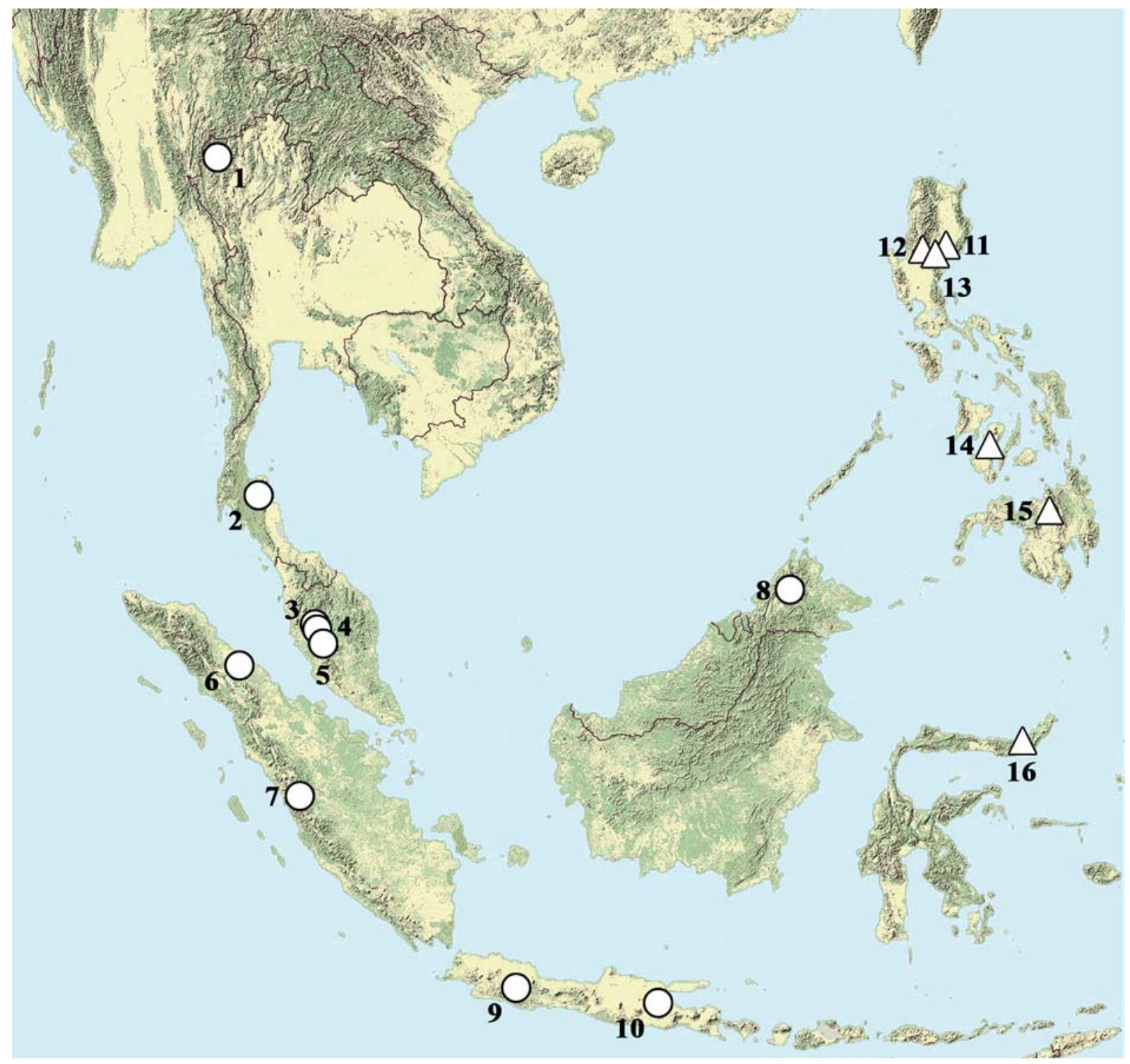

Fig. 44. Localities of Coptocercus spp.: 1-10-C. sumatranus stat.n.; 11-15-C. quatuordecimsignatus s. str.; 16 - C. q. celebensis. Thailand: 1 - Mae Hong Son, Ban Si Lang; 2 - Nakhon Si Thammarat, Mt. Khao Ram Rome. Malaysia: 3 - Pahang, Cameron Highlands; 4 - Cameron Highlands, Tanah Rata; 5 - Pahang, Bukit Fraser; 8 - Sabah, Crocker Range. Indonesia: 6 -North Sumatra, Pematang Siantar (type locality); 7 - West Sumatra, Mt. Talang; 9 - West Java, Mt. Cikuray; 10 — East Java, Mt. Butak. Philippines: 11 — Luzon, Quirino; 12 - Luzon, Imugan (type locality); 13 - Luzon, Aurora; 14 - Negros; 15 - Mindanao, Bukidnon. Indonesia: 16 - North Sulawesi, Mongondow (type locality).

Рис. 44. Местонахождения Coptocercus spp.: 1-10 - C. sumatranus stat.n.; 11-15 - C. quatuordecimsignatus s. str.; 16 - C. q. celebensis. Таиланд: 1 - Мае Хонг Сон (Мэхонгсон), Бан Си Ланг; 2 - Накхон Си Тхаммарат, гора Као Рам Рим. Малайзия: 3 - Паханг, Камерон Хайлендс; 4 - Камерон Хайлендс, Танах Рата; 5 - Паханг, Букит Фрейзер; 8 - Сабах, Крокер Рендж. Индонезия: 6 Северная Суматра, Пематанг Сиантар (типовое местонахождение); 7 - Западная Суматра, гора Таланг; 9 - Западная Ява, гора Чикурай; 10 - Восточная Ява, гора Бутак. Филиппины: 11 - Лусон, Кирино; 12 - Лусон, Имуган (типовое местонахождение); 13 Лусон, Аврора; 14 - Негрос; 15 - Минданао, Букиднон. Индонезия: 16 - Северный Сулавеси, Монгондоу (Болаанг-Монгондоу) (типовое местонахождение). 